\title{
The CCR5 $\triangle 32$ (rs333) polymorphism is not a predisposing factor for severe pandemic influenza in the Brazilian admixed population
}

\author{
Alvino Maestri ${ }^{1 *}$, Mirleide Cordeiro dos Santos ${ }^{2}$, Elzemar M Ribeiro-Rodrigues ${ }^{1}$, Wyller Alencar de Mello ${ }^{3}$, \\ Rita Catarina Medeiros Sousa ${ }^{3}$, Sidney Emanuel dos Santos ${ }^{1}$ and Vinicius Albuquerque Sortica ${ }^{4}$
}

\begin{abstract}
Background: Recent studies have tried to identify host genetic variants that could explain severe cases and deaths in infection with Influenza A(H1N1)pdm09, especially among children and young adults. CCR5 is a chemokine receptor expressed on T cells, macrophages and dendritic cells, which is an important mediator of leukocyte chemotaxis during the immune response. A deletion mutation $(\Delta 32)$ in this gene interferes with the response of immune cells, impairing viral clearance. We evaluated the CCR5 $\Delta 32$ polymorphism (rs333) in individuals of the Brazilian admixed population with a diagnosis of Influenza A(H1N1)pdm09 infection.

Methods: A total of 330 subjects with a diagnosis of Influenza A(H1N1)pdm09, evaluated at health services in the northern and northeastern regions of Brazil between June 2009 and August 2010, were genotyped for the $\Delta 32$ deletion (rs333). The cases were classified according to the progression of infection into a group of hospitalized patients $(n=156)$ and a group of non-hospitalized patients $(n=174)$.
\end{abstract}

Results: No significant differences in the allele or genotype frequencies of the CCR5 $\Delta 32$ polymorphism were observed between non-hospitalized and hospitalized patients ( $p=0.289$ and $p=0.431$, respectively).

Conclusion: The $\Delta 32$ deletion in the CCR5 gene is not associated with an unfavorable outcome in patients infected with Influenza A(H1N1)pdm09 in the Brazilian admixed population.

Keywords: A(H1N1)pdm09 infection, Influenza, CCR5 32

\section{Background}

On April 21, 2009 [1], the Centers for Disease Control and Prevention (CDC) announced two flu cases in children from California, USA, caused by a new influenza strain originated by the quadruple reassortment between other already circulating influenza viruses [2]. The new viral subtype spread around the world, a fact that culminated in the announcement by the World Health Organization (WHO) on June 11, 2009, of the first flu pandemic in the 21st century [3]. The lethality of the new viral strain did not add to the flu-related death statistics;

\footnotetext{
*Correspondence: alvimaestri@hotmail.com

1 Laboratório de Genética Humana e Médica, Universidade Federal do Pará, Cidade Universitária Prof. José da Silveira Neto, Rua Augusto Corrêa, 01, BOX: 8615, Belém, Pará CEP: 66.075-970, Brazil

Full list of author information is available at the end of the article
}

however, the large number of severe cases and deaths among children and young adults called the attention of the scientific community [4].

Recent studies have tried to identify host genetic variants that could explain severe cases of the disease [5]. On the basis of the cycle of viral replication of the pandemic strain in human cells, genetic variants that could influence viral clearance [6] have been identified. One genetic variant is a 32-bp deletion in the CCR5 gene $(\Delta 32)$ [7].

CCR5 is a chemokine receptor expressed on T cells, macrophages and dendritic cells, which is an important mediator of leukocyte chemotaxis during the response to chemokines. The interaction of this receptor with its ligands results in the homing of different immune cells to the sites of viral infection on the mucosal surface. Studies have shown that the $\triangle 32$ deletion in the CCR5 gene 
interferes with the response of immune cells through CCL3, CCL4 and CCL5, impairing viral clearance [8-10]. In a population of 20 Canadian patients who developed severe forms of infection with the pandemic flu virus, the mutation at position 32 of the CCR5 gene (rs333) was detected in five patients and was associated with an unfavorable clinical evolution [7]. However, the same mutation evaluated in 29 Italian patients also infected with the pandemic strain was not associated with poor clinical outcome [11]. In the present study, the CCR5 $\Delta 32$ polymorphism (rs333) was investigated in individuals from a Brazilian admixed population with a diagnosis of Influenza $\mathrm{A}(\mathrm{H} 1 \mathrm{~N} 1)$ pdm09 infection.

\section{Methods}

\section{Population}

Between June 2009 and August 2010, the Virology Section of the Evandro Chagas Institute (Seção de Virologia do Instituo Evandro Chagas-SEVIR/IEC) received 5,427 nasal swab or nasopharyngeal aspirate samples from subjects with a clinical suspicion of flu-like illness who sought health services in the states of the northern and northeastern regions of Brazil. Of these, 1,524 samples were positive for the pandemic strain and 330 samples with a diagnosis of Influenza A(H1N1)pdm09 were randomly included in the study. All patients enrolled in the study provided their written informed consent. Underage participants (younger than 18 years $n=115$ ) had the informed consents signed by parents to participate in the study. The study was approved by the Ethics Committee of the Center of Tropical Medicine, Federal University of Pará (Núcleo de Medicina Tropical, Universidade Federal do Pará).

\section{Laboratory diagnosis}

Diagnostic confirmation was performed at the Laboratory of Respiratory Viruses, SEVIR/IEC, Ananindeua, Pará, using the SuperScript III ${ }^{\mathrm{TM}}$ One-Step qRT-PCR System with Platinum Taq ${ }^{\circledR}$ (Invitrogen Life Technologies, Carlsbad, CA, USA) according to the protocol recommended by the CDC [12].

\section{Genotyping of CCR5 $\Delta 32$ (rs333)}

Genomic DNA was extracted from the leukocyte aggregate found in the nasal aspirate or nasopharyngeal swab using the QIAamp DNA Mini Kit (Qiagen, Valencia, CA, USA) according to manufacturer instructions. All DNA samples were genotyped by PCR. The primers (forward: CTCCCAGGAATCATCTTTACCA and reverse: TTTTTAGGATTCCCGAGTAGCA) were designed using the Primer3 software (http://www.genome.wi.mit.edu/cgibin/primer/primer3) and tested with the AutoDimer software.
PCR was carried out in a final volume of $12.5 \mu \mathrm{L}$ containing PCR buffer 1 with $3 \mathrm{mM}$ of $\mathrm{MgCl}_{2}, 125 \mathrm{mM}$ of each dNTP, 2 U Platinum AmpliTaq DNA polymerase (Invitrogen Life Technologies, Carlsbad, CA, USA) and 10-20 ng genomic DNA. The PCR conditions were: $11 \mathrm{~min}$ at $95^{\circ} \mathrm{C} ; 10$ cycles of $1 \mathrm{~min}$ at $94^{\circ} \mathrm{C}, 1 \mathrm{~min}$ at $60^{\circ} \mathrm{C}$ and $2 \mathrm{~min}$ at $70^{\circ} \mathrm{C} ; 17$ cycles of $1 \mathrm{~min}$ at $90^{\circ} \mathrm{C}, 1 \mathrm{~min}$ at $60^{\circ} \mathrm{C}$ and $2 \mathrm{~min}$ at $70^{\circ} \mathrm{C}$, and a final extension of $60 \mathrm{~min}$ at $60^{\circ} \mathrm{C}$. For capillary electrophoresis, $1 \mathrm{~mL}$ of the PCR product was added to $8.5 \mathrm{~mL} \mathrm{Hi-Di}$ formamide (Applied Biosystems, Foster City, CA, USA) and $0.5 \mathrm{~mL}$ GeneScan 500 LIZ Size Standard (Applied Biosystems, Foster City, CA, USA). The amplicons were separated in an ABI Prism 3130 Genetic Analyzer (Applied Biosystems, Foster City, CA, USA) and analyzed using the v3.2 GeneMapper ID software (Applied Biosystems, Foster City, CA, USA).

\section{Population substructure}

The proportions of African, European and Amerindian genetic ancestry of the infected patients were estimated using a panel of 48 ancestry-informative markers as described previously [13].

\section{Statistical analysis}

Allele and genotype frequencies were estimated by direct counting. Deviation from Hardy-Weinberg equilibrium was verified by Chi squared analysis. Differences in quantitative and qualitative characteristics between the groups of hospitalized and non-hospitalized patients were evaluated using the Student $t$ test, Chi squared test and Fisher's exact test. Differences in the proportions of genetic ancestry between groups were determined using the Wilcoxon-Mann-Whitney test. Fisher's exact test was used to analyze differences in the allele and genotype frequencies of the deletion studied between the groups of patients. Logistic regression was used to assess the effect of the CCR5 polymorphism on the severity of Influenza A(H1N1)pdm09 infection. European and African genetic ancestry and comorbidities (dichotomous variable, presence or not of comorbidity) were included in the model as confounders, as they presented differences between patients groups. Statistical analysis was performed using the SPSS 18.0 software, adopting a level of significance of $\mathrm{p}<0.05$.

\section{Results}

The 330 patients included in the study exhibited the classical clinical symptoms of the disease and were divided according to the progression of infection into two groups: patients that presented severe acute respiratory syndrome (SARS) and were hospitalized $(\mathrm{n}=156)$ following Brazilian Ministry of Health protocol [14] and 
patients with mild symptoms non-hospitalized $(\mathrm{n}=174)$ (Table 1). There was a predominance of women among the patients studied (61.5\%) and the mean patient age

\section{Table 1 Epidemiological and clinical characteristics of hos- pitalized and non-hospitalized patients infected with Influenza A(H1N1)pdm09}

\begin{tabular}{|c|c|c|c|c|}
\hline Characteristics & All patients & $\begin{array}{l}\text { Non-hospital- } \\
\text { ized }\end{array}$ & Hospitalized & $p$ value \\
\hline N & 330 & 174 & 156 & \\
\hline Female sex & $203(61.5)$ & $102(58.6)$ & $101(64.7)$ & 0.254 \\
\hline Age (years) & $24.7 \pm 15.3$ & $23.8 \pm 14.2$ & $25.8 \pm 16.5$ & 0.270 \\
\hline Pregnant & $47(31.8)$ & $19(26.0)$ & $28(37.3)$ & 0.140 \\
\hline Smoking & $18(5.5)$ & $6(3.4)$ & $12(7.7)$ & 0.090 \\
\hline \multicolumn{5}{|c|}{ Signs and symptoms } \\
\hline Fever & $320(97.0)$ & $167(96.0)$ & $153(98.1)$ & 0.267 \\
\hline Cough & $311(94.2)$ & $161(92.5)$ & $150(96.2)$ & 0.158 \\
\hline $\begin{array}{l}\text { Shortness of } \\
\text { breath }\end{array}$ & $245(74.2)$ & $101(58.0)$ & $144(92.3)$ & $<0.001$ \\
\hline Muscle aches & $212(64.2)$ & $117(67.2)$ & $95(60.9)$ & 0.230 \\
\hline Rhinorrhea & $197(59.7)$ & $113(64.9)$ & $84(53.8)$ & 0.040 \\
\hline Sore throat & $192(58.2)$ & $107(61.5)$ & $85(54.5)$ & 0.198 \\
\hline Chills & $138(41.8)$ & $72(41.4)$ & $66(42.3)$ & 0.864 \\
\hline Joint pain & $118(35.8)$ & $64(36.8)$ & $54(34.6)$ & 0.682 \\
\hline Headache & $63(19.1)$ & $40(23)$ & $23(14.7)$ & 0.057 \\
\hline Diarrhea & $55(16.7)$ & $24(13.8)$ & $31(19.9)$ & 0.139 \\
\hline Conjunctivitis & $21(6.4)$ & $15(8.6)$ & $6(3.8)$ & 0.076 \\
\hline $\begin{array}{l}\text { Abnormal chest } \\
\text { radiograph }\end{array}$ & $81(24.5)$ & $0(0)$ & $81(51.9)$ & $<0.001$ \\
\hline $\begin{array}{l}\text { Without } \\
\text { comorbidities }\end{array}$ & $220(66.7)$ & $128(73.6)$ & $92(59.0)$ & 0.005 \\
\hline \multicolumn{5}{|c|}{ With comorbidities } \\
\hline $\begin{array}{l}\text { Chronic lung } \\
\text { disorder }\end{array}$ & 65 (19.6) & $29(16.7)$ & $36(23.1)$ & 0.144 \\
\hline $\begin{array}{l}\text { Chronic car- } \\
\text { diovascular } \\
\text { condition }\end{array}$ & $22(6.6)$ & $10(5.7)$ & $12(7.7)$ & 0.470 \\
\hline $\begin{array}{l}\text { Metabolic } \\
\text { disorder }\end{array}$ & $12(3.6)$ & $1(0.6)$ & $11(7.1)$ & 0.002 \\
\hline $\begin{array}{l}\text { Immunosup- } \\
\text { pression }\end{array}$ & $7(2.1)$ & $0(0)$ & $7(4.5)$ & 0.005 \\
\hline Obesity & $8(2.4)$ & $1(0.6)$ & $7(4.5)$ & 0.021 \\
\hline $\begin{array}{l}\text { Hemoglobi- } \\
\text { nopathy }\end{array}$ & $3(0.9)$ & $1(0.6)$ & $2(1.3)$ & 0.490 \\
\hline $\begin{array}{l}\text { Chronic kidney } \\
\text { disease }\end{array}$ & $4(1.2)$ & $1(0.6)$ & $3(1.9)$ & 0.260 \\
\hline Death & $87(26.3)$ & $0(0)$ & $87(55.7)$ & $<0.001$ \\
\hline \multicolumn{5}{|l|}{ Genetic ancestry } \\
\hline $\begin{array}{l}\text { Native Ameri- } \\
\text { can }\end{array}$ & $0.264 \pm 0.18$ & $0.250 \pm 0.19$ & $0.280 \pm 19$ & 0.147 \\
\hline European & $0.574 \pm 0.20$ & $0.600 \pm 0.20$ & $0.544 \pm 19$ & 0.006 \\
\hline African & $0.162 \pm 0.11$ & $0.150 \pm 0.10$ & $0.176 \pm 11$ & 0.010 \\
\hline
\end{tabular}

Age and genetic ancestry were reported as the mean \pm SD. All other variables are reported as number (\%) was 24.7 years (1-80 years). Forty-seven of the women were pregnant and 28 were hospitalized. Radiologic alterations were found in $51.9 \%$ of hospitalized patients. Most hospitalized patients had no comorbidities (59\%). However, patients with comorbidities (metabolic disorders, immunosuppression and obesity) were significantly more frequent in the group of hospitalized patients. Deaths occurred in $55.7 \%$ of hospitalized patients. The population studied exhibited a mean European genetic contribution of $57.4 \%$, a mean Native American contribution of $26.4 \%$ and a mean African contribution of $16.2 \%$ (Table 1) in agreement with previously data from Brazilian populations $[13,15]$. In non-hospitalized patients the mean European contribution was $60 \%$ ranging from 4.6 to $91.9 \%$, the mean Native American contribution was $25 \%$ ranging from 3.2 to $93.2 \%$, and the mean African contribution was $15 \%$ ranging $2.2-61 \%$. In hospitalized patients, genetic contribution was European $54.4 \%$ ranging from 5.9 to $93 \%$, Native American 28\% ranging from 3.5 to $90.6 \%$, and African 17,6\% ranging 2.4-67.6\% (Additional files 1,2). European and African genetic ancestry showed statistical differences between groups $(\mathrm{p}=0.006$ and $\mathrm{p}=0.010$, respectively).

There were no significant differences in the allele or genotype frequencies of the CCR5 $\triangle 32$ polymorphism between non-hospitalized and hospitalized patients ( $\mathrm{p}=0.289$ and 0.431 , respectively) (Table 2 ). A logistic regression analysis was performed to assess the effect of CCR5 $\triangle 32$ polymorphism on infection severity controlling for European and African ancestry and the presence of comorbidities to avoid confounding effects. No association between patients carrying the $\Delta 32$ allele and severity was found (Table 3).

\section{Discussion}

Since the demonstration of the protective role of a 32-bp deletion in the CCR5 gene in two individuals exposed to, but not infected with HIV [16], studies on the protective or regulatory role of this deletion have multiplied [17].

Table 2 Genotype and allele distribution of $\operatorname{CCR} 5 \Delta 32$ in non-hospitalized and hospitalized patients infected with Influenza A(H1N1)pdm09

\begin{tabular}{lccc}
\hline & Non-hospitalized & Hospitalized & p value \\
\hline Genotype & & & \\
Wt/Wt & $160(92.0)$ & $148(94.9)$ & 0.431 \\
Wt/ 32 & $13(7.5)$ & $8(5.1)$ & \\
$\Delta 32 / \Delta 32$ & $1(0.6)$ & $0(0)$ & \\
Allele & & & \\
Wt & $333(0.96)$ & $304(0.97)$ & 0.289 \\
$\Delta 32$ & $15(0.04)$ & $8(0.03)$ & \\
\hline
\end{tabular}


Table 3 CCR5 332 effect on A(H1N1)pdm09 infection severity

\begin{tabular}{lllll}
\hline Genotypes & B & OR & Cl 95\% & P value \\
\hline$W t / \mathrm{Wt}^{\mathrm{a}}$ & & & & \\
$\Delta 32$ carriers $^{\mathrm{b}}$ & -0.582 & 0.559 & $0.22 ; 1.26$ & 0.219
\end{tabular}

Covariates in Regression model: European and African ancestry and comorbidities.

a Reference genotype.

b $\mathrm{Wt} / \mathrm{Wt}+\mathrm{Wt} / \Delta 32$.

The protective role of this polymorphism in HIV infection was extensively studied and utilized as model for the development of new therapeutics for AIDS [18].

However, the presence of the deletion can be a determinant factor of morbidity and mortality in the case of other infectious diseases. In a meta-analysis of four cohorts evaluating the deletion in patients with West Nile fever, genetic deficiency of the CCR5 gene was a strong risk factor of symptomatic arbovirus infection [19]. In another study comparing 129 patients with a diagnosis of tickborne encephalitis virus infection and 79 subjects with aseptic meningitis negative for tickborne encephalitis and 134 healthy controls, a higher frequency of the homozygous $\Delta 32 / \Delta 32$ genotype was observed among patients with tickborne encephalitis, particularly among severe cases of the disease [20].

In the present study, no difference in the $\Delta 32$ deletion of the CCR5 gene was observed between the groups of individuals infected with Influenza A(H1N1)pdm09 in a Brazilian admixed population, who presented the classical clinical symptoms [21]. Thus, no correlation could be established between the presence of the mutation and a more severe outcome of the disease. The present results agree with those reported in a recent study involving an Italian population [11], but disagree with the findings obtained for a Canadian population [7].

The Brazilian population was formed by extensive admixture of Native American, European and African populations, nevertheless European genetic ancestry is predominantly in Brazil $[13,15]$. In the population studied the mean European contribution was around $57 \%$ and the CCR5 $\triangle 32$ allele frequency was $3.6 \%$, similar to previously described for Brazilian populations [22]. Despite ethnic differences with the populations previously analyzed, in the present study thirteen heterozygous and one homozygous for the $\Delta 32$ deletion were found in patients with mild symptoms and eight heterozygous for this deletion were found in hospitalized group showing no evidence of this allele effect on severity.

Previous researches adopted different criteria for severe patients $[7,11]$, which could contribute for conflicting results among studies, but despite those differences, we emphasize the large size of the sample studied here compared to previously published studies, supporting the hypothesis that the $\Delta 32$ mutation is not a predisposing factor for severe Influenza A(H1N1)pdm09 infection.

\section{Conclusion}

Although studies have reported an association between mutation $\Delta 32$ in the CCR5 gene and a more severe evolution of some infectious diseases, our findings demonstrate that the same cannot be confirmed for infection with Influenza A(H1N1)pdm09 in the Brazilian admixed population.

\section{Additional files}

Additional file 1: Genetic ancestry admixture of patients infected with Influenza A(H1N1)pdm09 sorted by African ancestry. Each individual ancestry is depicted as a column, whereas color represents the proportion of ancestry estimated for that individual (African = blue; European = brown; Native American = green). (A) Non-hospitalized patients and (B) Hospitalized patients.

Additional file 2: Genetic ancestry admixture of patients infected with Influenza A(H1N1)pdm09 sorted by European ancestry. Each individual ancestry is depicted as a column, whereas color represents the proportion of ancestry estimated for that individual (African = blue; European = brown; Native American = green). (A) Non-hospitalized patients and (B) Hospitalized patients.

\section{Abbreviations}

CDC: Centers for Disease Control and Prevention; IEC: Evandro Chagas Institute; SEVIR: Virology Section; WHO: World Health Organization.

\section{Authors' contributions}

AMN designed the study concepts, conducted the study and prepared the manuscript. VAS performed the data analysis and interpretation and drafted the manuscript. MCS, EMR and WAS were involved in sample and data collection, and final approval of the manuscript SEB and RCM designed the study concepts, drafting the manuscript and final approval of the manuscript. All authors read and approved the final manuscript.

\section{Author details}

${ }^{1}$ Laboratório de Genética Humana e Médica, Universidade Federal do Pará, Cidade Universitária Prof. José da Silveira Neto, Rua Augusto Corrêa, 01, BOX: 8615, Belém, Pará CEP: 66.075-970, Brazil. ${ }^{2}$ Laboratory of Respiratory Viruses, Virology Section, Evandro Chagas Institute, Ananindeua, Pará, Brazil. ${ }^{3}$ Tropical Medicine Institute, Federal University of Pará, Belém, Pará, Brazil. ${ }^{4}$ Center of Cancer Research, Federal University of Pará, Belém, Pará, Brazil.

\section{Acknowledgements}

AMN was the recipient of a Doctoral fellowship from the Brazilian Ministry of Health (Coordenação de Aperfeiçoamento de Pessoal de Nível SuperiorCAPES) and the Abroad Sandwich Doctorate Program (Programa de Doutorado Sanduíche no Exterior-PDSE). The authors thank the financial support provided by Conselho Nacional de Desenvolvimento Científico e Tecnológico (CNPq, Brazil), Programa de Pesquisa para o Sistema Único de Saúde (PPSUS) e CAPES. The funders had no role in study design, data collection and analysis, decision to publish, or preparation of the manuscript.

\section{Compliance with ethical guidelines}

\section{Competing interests}

The authors declare that they have no competing interests. 
Received: 13 January 2015 Accepted: 22 July 2015

Published online: 30 July 2015

\section{References}

1. Centers for Diseases Control and Prevention (2009) Swine influenza A (H1N1) infection in two children-Southern California, March-April 2009. MMWR Morb Mortal Wkly Rep 58(15):400-402

2. Neumann G, Noda T, Kawaoka Y (2009) Emergence and pandemic potential of swine-origin H1N1 influenza virus. Nature 459(7249):931-939

3. World Health Organization (2009) Influenza A(H1N1) in the Americas, vol 21. In: Pan American Health Organization (ed) World Health Organization, p 2

4. Fineberg HV (2014) Pandemic preparedness and response-lessons from the H1N1 influenza of 2009. N Engl J Med 370(14):1335-1342

5. Keynan Y, Malik S, Fowke KR (2013) The role of polymorphisms in host immune genes in determining the severity of respiratory illness caused by pandemic H1N1 influenza. Public Health Genomics 16(1-2):9-16

6. Zhang L, Katz JM, Gwinn M, Dowling NF, Khoury MJ (2009) Systemsbased candidate genes for human response to influenza infection. Infect Genet Evol 9(6):1148-1157

7. Keynan Y, Juno J, Meyers A, Ball TB, Kumar A, Rubinstein E et al (2010) Chemokine receptor $5 \Delta 32$ allele in patients with severe pandemic (H1N1) 2009. Emerg Infect Dis 16(10):2

8. Sanchooli J, Sanadgol N, Kazemi Arababadi M, Kennedy D (2014) CCR5 plays important roles in hepatitis B infection. Viral Immunol 27(1):2-6

9. Samson M, Labbe O, Mollereau C, Vassart G, Parmentier M (1996) Molecular cloning and functional expression of a new human CC-chemokine receptor gene. Biochemistry 35:6

10. Ghorban K, Dadmanesh M, Hassanshahi G, Momeni M, Zare-Bidaki M, Arababadi MK et al (2012) Is the CCR5 $\Delta 32$ mutation associated with immune system-related diseases? Inflammation 36(3):633-642

11. Sironi M, Cagliani R, Pontremoli C, Rossi M, Migliorino G, Clerici M et al (2014) The CCR5 $\Delta 32$ allele is not a major predisposing factor for severe H1N1pdm09 infection. BMC Research Notes 7(1):504
12. Centers for Diseases Control and Prevention (2009) CDC protocol of realtime RTPCR for influenza A(H1N1). In: Centers for Disease Control and Prevention, Atlanta, p 7

13. Santos NPC, Ribeiro-Rodrigues EM, Ribeiro-dos-Santos ÂKC, Pereira R, Gusmão L, Amorim A et al (2010) Assessing individual interethnic admixture and population substructure using a 48-insertion-deletion (INSEL) ancestry-informative marker (AIM) panel. Hum Mutat 31(2):184-190

14. Ministério da Saúde do Brasil (2009) Brasil: Protocolo de manejo clínico e vigilância epidemiológica da influenza. In: SVS, Brasília, p 32

15. Saloum de Neves Manta F, Pereira R, Vianna R, Rodolfo Beuttenmüller de Araújo A, Leite Góes Gitaí D, Aparecida da Silva D et al (2013) Revisiting the genetic ancestry of Brazilians using autosomal AIM-Indels. PLoS One 8(9):e75145

16. Liu R, Paxton WA, Choe S, Ceradini D, Martin SR, Horuk R et al (1996) Homozygous defect in HIV-1 coreceptor accounts for resistance of some multiply-exposed individuals to HIV-1 infection. Cell 86:11

17. Klein Robyn S (2008) A moving target: the multiple roles of CCR5 in infectious diseases. J Infect Dis 197(2):183-186

18. O'Brien SJ, Hendrickson SL (2013) Host genomic influences on HIV/AIDS Genome Biol 14(1):201-213

19. Lim Jean K, Louie Christine $Y$, Glaser C, Jean C, Johnson B, Johnson H et al (2008) Genetic deficiency of chemokine receptor CCR5 is a strong risk factor for symptomatic West Nile virus infection: a meta-analysis of 4 cohorts in the US epidemic. J Infect Dis 197(2):262-265

20. Kindberg E, Mickienè A, Ax C, Åkerlind B, Vene S, Lindquist L et al (2008) A deletion in the chemokine receptor 5(CCR5) gene is associated with tickborne encephalitis. J Infect Dis 197(2):266-269

21. Bautista E, Chotpitayasunondh T, Gao Z, Harper SA, Shaw M, Uyeki TM et al (2010) Clinical aspects of pandemic 2009 influenza A (H1N1) virus infection. N Engl J Med 362(18):1708-1719

22. Vargas AE, Marrero AR, Salzano FM, Bortolini MC, Chies JA (2006) Frequency of CCR5delta32 in Brazilian populations. Braz J Med Biol Res 39(3):321-325

\section{Submit your next manuscript to BioMed Central and take full advantage of:}

- Convenient online submission

- Thorough peer review

- No space constraints or color figure charges

- Immediate publication on acceptance

- Inclusion in PubMed, CAS, Scopus and Google Scholar

- Research which is freely available for redistribution

Submit your manuscript at

www.biomedcentral.com/submit

C BioMed Central 